\section{LEGALISASI TINDAKAN ABORSI DALAM HAL PEMERKOSAAN DITINJAU DARI UNDANG- UNDANG NOMOR 36 TAHUN 2009 TENTANG KESEHATAN DAN PERATURAN PEMERINTAH NOMOR 61 TAHUN 2014 TENTANG REPRODUKSI ${ }^{1}$ Oleh : Ayu Srihartini ${ }^{2}$}

\begin{abstract}
ABSTRAK
Tujuan dilakukannya penelitian ini adalah untuk mengetahui bagaimana pandangan norma dalam kehidupan bermasyarakat terkait legalisasi aborsi akibat pemerkosaan dan bagaimana penerapan dan pengaturan legalisasi aborsi akibat pemerkosaan yang sesuai dengan Peraturan Perundang-undangan yang berlaku. Dengan menggunakan metode penelitian yuridis normatif, disimpulkan: 1 . Pembenaran aborsi bagi korban pemerkosaan didasarkan pada Pasal 75 Undang-Undang Nomor 36 Tahun 2009 tentang Kesehatan dan Pasal 31 Peraturan Pemerintah Nomor 61 Tahun 2014 tentang Kesehatan Reproduksi. Perlindungan dan pengakuan terhadap hak reproduksi pada prinsipnya merupakan pengakuan terhadap hak untuk hidup dan mempertahankan hidupnya. Hak setiap perempuan untuk mendapatkan kehidupan yang sehat secara lahir batin dan sosial dalam lingkup perlindungan hukum. Dalam hal ini artinya apabila ada hal-hal yang mengancam hidup dan kehidupan perempuan yang menyebabkan dirinya berada dalam keadaan yang tidak sehat dan sejahterah maka ia berhak diberikan pelayanan kesehatan dan perlindungan hukum sesuai kebutuhan dirinya. 2. Legalisasi abortus provocatus karena pemerkosaan merupakan suatu implementasi pemenuhan hak asasi perempuan terutama di bidang kesehatan reproduksi. Meski sebagian besar instrument HAM dan peraturan perundang-undangan tentang HAM tidak memberikan pernyataan eksplisit namun hak menentukan diri sendiri untuk mendapatkan hak atas derajat kesehatan yang setinggitingginya termasuk di dalam menentukan kapan seorang perempuan akan hamil dan melahirkan.
\end{abstract}

\footnotetext{
${ }^{1}$ Artikel Skripsi. Dosen Pembimbing: Mien Soputan, S.H., M.H; Herry F. Tuwaidan, S.H., M.H.

2 Mahasiswa pada Fakultas Hukum Unsrat, NIM. 16071101083
}

Kata kunci: Legalisasi, Tindakan Aborsi, Pemerkosaan, Kesehatan, Reproduksi

\section{PENDAHULUAN}

\section{A. Latar Belakang}

Untuk mengantisipasi dan melindungi kaum perempuan korban pemerkosaan dan menjaga kaum ibu muda masa mendatang, maka pemerintah mengeluarkan Peraturan Pemerintah No.61 Tahun 2014 tentang Kesehatan Reproduksi. Dalam Pasal 31 diatur bahwa aborsi di perbolehkan untuk kehamilan akibat pemerkosaan, dan hanya dapat dilakukan jika umur kehamilan di bawah 40 hari. Dengan asumsi bahwa di bawah 40 hari belum ada kehidupan, yakni belum ditiupkannya ruh ke dalam janin. Dengan demikian, logika hukumnya karena belum ada kehidupan, maka aborsi yang dilakukan belum mengandung unsur-unsur pembunuhan, tetapi lebih menekankan pada kebaikan bagi perempuan korban pemerkosaan. ${ }^{3}$

Pasal 75 ayat (2) Undang-Undang No.36 Tahun 2009 menyebutkan bahwa "larangan sebagaimana dimaksud pada ayat (1) dapat dikecualikan berdasarkan: a. indikasi kedaruratan medis yang dideteksi sejak usia kehamilan, baik yang mengancam nyawa ibu dan/atau janin, yang menderita penyakit genetic berat dan/atau cacat bawaan, maupun yang tidak dapat diperbaiki sehingga menyulitkan bayi tersebut hidup diluar kandungan; atau b. Kehamilan akibat pemerkosaan yang dapat menyebabkan trauma psikologis bagi korban pemerkosaan". 4

Mengenai tindakan aborsi ini, UndangUndang Nomor 36 tahun 2009 yang menggantikan Undang-Undang Nomor 23 tahun 1992 tentang Kesehatan pada prinsipnya sejalan dengan ketentuan pidana yang ada, yaitu melarang setiap orang untuk melakuan aborsi. Namun, dalam tataran bahwa negara harus melindungi warganya, dalam hal ini perempuan yang melakukan aborsi berdasarkan indikasi kedaruratan medis dan

\footnotetext{
3 Rohmawati, "Tinjauan Hukum Islam Terhadap Legalitas Aborsi Akibat Pemerkosaan Dalam PP No.61 Tahun 2014", Artikel dimuat dalam: Jurnal Ahkam, Volume 3, No.1, Juli 2015.

${ }^{4}$ Lihat Undang-Undang Nomor 36 Tahun 2009 tentang Kesehatan dan Tenaga Kesehatan, Pasal 75.
} 
akibat pemerkosaan, serta melindungi tenaga medis yang melakukannya.

Undang-Undang Nomor 36 tahun 2009 tentang Kesehatan membuka pengecualian untuk aborsi berdasarkan indikasi kedaruratan medis dan kehamilan akibat pemerkosaan. Dalam Pasal 75 ayat (2) Undang-Undang Nomor 36 tahun 2009 disebutkan bahwa aborsi dapat dilakukan dalam kondisi tertentu yaitu indikasi medis dan pemerkosaan. Pada ayat 4 UndangUndang Nomor 36 tahun 2009 menyatakan bahwa ketentuan lebih lanjut mengenai indikasi kedaruratan medis dan pemerkosaan sebagai syarat pengecualian dilakukannya aborsi diatur lebih lanjut dengan Peraturan Pemerintah. Peraturan Pemerintah yang dimaksud yaitu Peraturan Pemerintah Nomor 61 tahun 2014 tentang Kesehatan Reproduksi. Di jelaskan bahwa dengan alasan korban pemerkosaan maka seseorang dapat dengan legal melakukan aborsi. $^{5}$

\section{B. Rumusan Masalah}

1. Bagaimanakah pandangan norma dalam kehidupan bermasyarakat terkait legalisasi aborsi akibat pemerkosaan?

2. Bagaimanakah penerapan dan pengaturan legalisasi aborsi akibat pemerkosaan yang sesuai dengan Peraturan Perundang-undangan yang berlaku?

\section{Metode Penelitian}

Dalam penelitian ini yang digunakan adalah metode kepustakaan, yang bersifat yuridis normatif dengan cara mengumpulkan bahanbahan hukum melalui penelitian kepustakaan.

Diharapkan penelitian ini memberi manfaat dan pengetahuan yang lebih dalam perihal legalisasi aborsi akibat pemerkosaan sebelum tindakan medis aborsi dilakukan oleh tenaga kesehatan. Hal ini penting mengingat perlunya menjaga eksistensi manusia dan juga memperhatikan keselamatan wanita yang mengandung dan kandungan yang akan lahir dalam keadaan yang sehat namun di sisi lain juga guna memberi pedoman kepastian pada tenaga kesehatan agar sebelum melakukan

\footnotetext{
${ }^{5}$ Waluyadi, IImu Kedokteran Kehamilan Dalam Perspektif Peradilan dan Aspek Hukum Praktik Kedokteran, Djambatan, Jakarta, hal. 82
}

tindakan medis tetap mengacu pada peraturanperaturan yang diberlakukan. ${ }^{6}$

\section{PEMBAHASAN}

\section{A. Pandangan Norma Dalam Masyarakat} Terkait Legalisasi Aborsi

Dalam kehidupan sosial, hamil akibat pemerkosaan merupakan masalah yang dilematis. Di satu sisi, rasanya tidak adil jika wanita yang menjadi korban pemerkosaan meneruskan kehamilannya sampai tiba waktu melahirkan dan anak yang dilahirkan menjadi cemohan masyarakat yang dapat mengakibatkan ibunya menjadi trauma karena adanya cemohan tersebut. Sehingga dengan memaksanya untuk meneruskan kehamilannya dapat menimbulkan trauma dan depresi bagi wanita itu sendiri dan keluarganya seumur hidupnya ${ }^{7}$.

$\mathrm{Di}$ kalangan bermasyarakat di negara Indonesia, ibu dan anak hasil dari pemerkosaan selalu dinilai negatif. Oleh karena itu dahulu kala, seorang perempuan yang sudah diperkosa biasanya langsung dipaksa kawin dengan orang lain oleh orangtuanya. Hal ini dilakukan demi menghilangkan aib pemerkosaan yang dialami. Namun, hal itu bukan berarti aborsi tidak pernah menjadi pilihan bagi orangtua yang anaknya diperkosa.

Zaman dahulu aborsi karena pemerkosaan pernah dilakukan. Tentu tidak di rumah sakit dan ditangani oleh orang yang berkompeten di bidangnya tapi di dukun beranak yang tentu masih diragukan profesionalitasnya. Tentu hal ini dilakukan demi menutupi aib akibat pemerkosaan tersebut. Jadi dari sisi norma kesopanan dan kesusilaan yang hidup di masyarakat kita, aborsi karena pemerkosaan bukanlah hal yang tabu. Aborsi merupakan suatu tindakan pilihan bagi keluarga yang putrinya mengalami kehamilan akibat pemerkosaan. $^{8}$

\footnotetext{
6 Soerjono Soekanto, Pengantar Penelitian Hukum, Cetakan III, Jakarta Badan Penerbit Fakultas Hukum Universitas Indonesia, 2005, hal.4.

7 Saifullah, Aborsi dan Pertimbangan Hukum Terhadap Kasus Pemerkosaan, Artikel dimuat dalam Jurnal Mimbar Hukum, vol. 3, no.2, Juli 2013 hlm, 28.

" "Keteraturan Sosial, Norma Dan Hukum", https://media.neliti.com /meia/publications/ 80721-IDketeraturan-sial-norma-dan-hukum-sebua.pdf diakses pada tanggal 28 Oktober 2019, Pukul 13:20 Wita.
} 
Dengan disahkannya Undang-Undang Nomor 36 Nomor 2009 tentang Kesehatan yang menggantikan Undang-Undang kesehatan sebelumnya yaitu Undang-Undang Nomor 23 Tahun 1992, maka permasalahan aborsi memperbolehkan legitimasi dan penegasan. Dalam undang-undang ini terdapat pasal-pasal yang mengatur mengenai aborsi, meskipun dalam praktek medis mengandung berbagai reaksi dan menimbulkan kontroversi di berbagai lapisan masyarakat. Meskipun, undang-undang melarang praktek aborsi, tetapi dalam keadaan tertentu terdapat kebolehan. Ketentuan pengaturan aborsi dalam UndangUndang Nomor 36 Tahun 2009 dituangkan dalam Pasal 75, 76, 77, dan $194 .^{9}$

Berikut ini adalah uraian lengkap mengenai pengaturan aborsi yang terdapat dalam pasalpasal tersebut :

Pasal 75 Undang-Undang Nomor 36 tahun 2009, disebutkan bahwa :

1) Setiap orang dilarang melakukan aborsi.

2) Larangan sebagaimana dimaksud pada ayat

(1) dapat dikecualikan berdasarkan:

a) Indikasi kedaruratan medis yang dideteksi sejak usia dini kehamilan, baik yang mengancam nyawa ibu dan/atau janin, yang menderita penyakit genetik berat dan/atau cacat bawaan, maupun yang tidak dapat diperbaiki sehingga menyulitkan bayi tersebut hidup diluar kandungan.

b) Kehamilan akibat pemerkosaan yang dapat menyebabkan trauma psikologis bagi korban pemerkosaan.

3) Tindakan sebagaimana dimaksud pada ayat (2) hanya dapat dilakukan setelah melalui konseling dan/atau penasehatan pra tindakan dan diakhiri dengan konseling pasca tindakan yang dilakukan oleh konselor yang kompeten dan berwenang.

4) Ketentuan lebih lanjut mengenai indikasi kedaruratan medis dan pemerkosaan, sebagaimana dimaksud pada ayat (2) dan ayat (3) diatur dengan Peraturan Pemerintah.

Pasal 76 dalam Undang-Undang Nomor 36 tahun 2009 dipertegas lagi bahwa aborsi sebagaimana dimaksud dalam Pasal 75 hanya dapat dilakukan:

\footnotetext{
${ }^{9}$ Soekidjo Notoatmodjo, Etik dan Hukum Kesehatan, PT. Rineka Cipta, Jakarta, 2010, Hal. 135-136.
}

a) Sebelum kehamilan berumur 6 (enam) minggu dihitung dari hari pertama haid terakhir, kecuali dalam hal kedaruratan medis.

b) Oleh tenaga kesehatan yang memiliki keterampilan dan kewenangan yang memiliki sertifikat dan yang ditetapkan oleh Menteri.

c) Dengan persetujuan ibu hamil yang bersangkutan.

d) Dengan izin suami, kecuali korban pemerkosaan.

e) Penyedia layanan kesehatan yang memenuhi syarat yang ditetapkan oleh Menteri.

Pasal 77 Undang-Undang Nomor 36 tahun 2009, disebutkan bahwa:

"Pemerintah wajib melindungi dan mencegah wanita dari aborsi sebagaimana dimaksud dalam Pasal 75 ayat (2) dan ayat (3) yang tidak bermutu, tidak aman, dan tidak bertanggung jawabserta bertentangan dengan norma agama, dan ketentuan peraturan Perundang-undangan." ${ }^{10}$

Pasal 194 Undang-Undang Nomor 36 tahun 2009, disebutkan bahwa:

"Setiap orang dengan sengaja melakukan aborsi tidak sesuai dengan ketentuan sebagaimana dimaksud dalam Pasal 75 ayat (2) dipidana dengan pidana penjara paling lama sepuluh tahun dan denda paling banyak $\mathrm{Rp}$ 1.000.000.000,00 (satu miliar rupiah)."11

Dengan demikian pada saat ini tindakan aborsi karena pemerkosaan telah mendapat payung hukum yang cukup kuat dalam masyakarakat. Salah satu pembelaan terhadap legalisasi tersebut tentunya akan bersumber pada eksistensi hak asasi perempuan itu sendiri. ${ }^{12}$

\section{B. Penerapan dan Pengaturan Abortus Yang Sesuai Dengan Peraturan Perundang- Undangan Yang Berlaku \\ 1. Pandangan Peraturan Pemerintah Nomor 61 Tahun 2014}

\footnotetext{
${ }^{10}$ Lihat Undang-Undang Nomor 36 Tahun 2009, tentang Kesehatan, Pasal 75-77.

${ }^{11}$ Lihat Undang-Undang Nomor 36 Tahun 2009, tentang Kesehatan, Pasal 194.

${ }^{12}$ Mufliha Wijayati, "Aborsi Akibat Kehamilan Yang Tidak Di inginkan", Artikel dimuat dalam: Jurnal Studi Keislaman, Vol.5, No.1, Juni 2015.
} 
Abortus provocatus medicinalis secara hukum dibenarkan dan mendapat pelindungan hukum sebagaimana diatur dalam Pasal 75 ayat (2) Undang-Undang Nomor 36 Tahun 2009 tentang Kesehatan. Dalam ketentuan Pasal 75 ayat (2) disebutkan bahwa; Larangan sebagaimana dimaksud pada ayat (1) dapat dikecualikan berdasarkan: Indikasi kedaruratan medis sejak usia dini kehamilan, baik yang mengancam nyawa ibu dan/janin, yang menderita penyakit genetik berat dan/atau cacat bawaan, maupun yang tidak dapat diperbaiki sehingga menyulitkan bayi tersebut hidup diluar kandungan; atau akibat pemerkosaan yang menyebabkan trauma psikologis bagi korban pemerkosaan. ${ }^{13}$

Aborsi legal untuk dilakukan terhadap kehamilan akibat pemerkosaan yang dapat menyebabkan trauma psikologis bagi korban pemerkosaan. Meskipun demikian tindakan aborsi akibat pemerkosaan hanya dapat dilakukan setelah melalui konseling dan/atau penasehatan pra tindakan dan diakhiri dengan konseling pasca tindakan yang dilakukan oleh konselor dan berwenang sebagaimana diatur dalam Pasal 75 ayat (3) Undang-Undang Nomor 36 Tahun 2009 tentang Kesehatan. ${ }^{14}$

Ketentuan Pasal 194 Undang-Undang Nomor 36 Tahun 2009 tentang Kesehatan mengatur bahwa, "sanksi bagi setiap orang yang dengan sengaja melakukan aborsi yang tidak sesuai dengan ketentuan Pasal 75 ayat (2) Undang-Undang Kesehatan di pidana dengan pidana penjara paling lama 10 tahun dan denda paling banyak Rp. 1 Miliar". ${ }^{15}$

Sebagai pelaksana dari Undang-Undang Nomor 36 Tahun 2009 tentang Kesehatan, kini pemerintah telah menerbitkan Peraturan Nomor 61 Tahun 2014 tentang Kesehatan Reproduksi.

Ketentuan legalitas aborsi terhadap kehamilan akibat pemerkosaan diatur dalam Pasal 31 ayat (1) dan (2) Peraturan Pemerintah Nomor 61 Tahun 2014. Pasal 31 ayat (1) dan (2) mengatur bahwa tindakan aborsi hanya dapat dilakukan pada kehamilan akibat pemerkosaan dan hanya dapat dilakukan apabila usia kehamilan paling lama berusia 40 hari dihitung

\footnotetext{
13 Abdul Mun'im Idries, Pedoman Ilmu Kedokteran Forensik, Jakarta, Binarupa Aksara, 2007, hal.19.

${ }^{14}$ Abdul Mun'im Idries, Op.Cit, hal.28.

${ }^{15}$ Lihat Undang-Undang Nomor 36 Tahun 2009, Pasal 75.
}

sejak hari pertama haid terakhir. Ketentuan Pasal 34 ayat (2) Peraturan Pemerintah Nomor 61 Tahun 2014 mengatur bahwa kehamilan akibat pemerkosaan harus dibuktikan dengan:

a) Usia kehamilan sesuai dengan kejadian pemerkosaan, yang dinyatakan oleh surat keterangan dokter,

b) Keterangan penyidik, psikolog, dan/atau ahli lain mengenai adanya dugaan pemerkosaan.

Adapun yang dimaksud dengan "ahli lain" berdasarkan penjelasan Pasal 34 ayat (2) huruf b Peraturan Pemerintahan Nomor 61 Tahun 2014 antara lain dokter spesialis psikiater, dokter spesialis forensik, dan pekerja sosial. ${ }^{16}$

Aborsi akibat pemerkosaan harus dilakukan dengan aman, bermutu, dan bertanggungjawab sebagaimana dimaksud dalam ketentuan Pasal 35 ayat (1) Peraturan Pemerintah Nomor 61 tahun 2014. Ketentuan ini mengatur bahwa wanita hamil yang ingin melakukan aborsi berhak untuk mendapatkan pelayanan aborsi yang aman, bermutu, dan bertanggungjawab. Hak-hak wanita korban pemerkosaan yang ingin melakukan aborsi tercermin dalam pengaturan dalam Pasal 37 Peraturan Pemerintah Nomor 61 Tahun 2014 yang mengatur bahwa tindakan aborsi akibat pemerkosaan hanya dapat dilakukan melalui konseling, yaitu pra konseling dan pasca konseling.

Adapun tujuan pra konseling adalah sebagaimana diatur dalam ketentuan Pasal 37 ayat (3) Peraturan Pemerintah Nomor 61 Tahun 2014 adalah:

1. Menjajaki kebutuhan dari perempuan yang ingin melakukan aborsi

2. Menyampaikan dan menjelaskan kepada perempuan yang ingin melakukan aborsi bahwa tindakan aborsi dapat atau tidak dapat dilakukan berdasarkan hasil pemeriksaan klinis dan pemeriksaan penunjang.

3. Menjelaskan tahapan tindakan aborsi yang akan dilakukan dan kemungkinan efek samping atau komplikasinya

4. Membantu perempuan yang ingin melakukan aborsi untuk mengambil keputusan sendiri untuk melakukan aborsi atau membatalkan keinginan

\footnotetext{
${ }^{16}$ Abdul Wahid \& Muhammad Irfan, Perlindungan Korban Kekerasan Seksual, PT. Refika Aditama, Cetakan Kedua, Bandung, 2011,hal.12.
} 
untuk melakukan aborsi setelah mendapatkan informasi mengenai aborsi

5. Menilai kesiapan pasien untuk menjalani aborsi. $^{17}$

Ketentuan Pasal 37 ayat (4) Peraturan Pemerintahan Nomor 61 Tahun 2014 menjelaskan bahwa konseling pasca tindakan dilakukan dengan tujuan:

1. Mengobservasi dan mengevaluasi kondisi pasien setelah tindakan aborsi

2. Membantu pasien memahami keadaan atau kondisi fisik setelah menjalani aborsi

3. Menjelaskan perlunya kunjungan ulang untuk pemeriksaan dan konseling lanjutan atau tindakan rujukan bila diperlukan

4. Menjelaskan pentingnya penggunaan alat kontrasepsi untuk mencegah terjadinya kehamilan. ${ }^{18}$

Dapat disimpulkan bahwa korban pemerkosaan mempunyai hak antara lain yaitu untuk mendapatkan pelayanan aborsi yang aman sesuai standart kesehatan yang ditentukan sesuai dengan ketentuan, karena Menurut teori hukum seseorang dapat dikategorikan sebagai pelaku tindak pidana "pelaku pemerkosaan" apabila sudah ada putusan hakim yang berkekuatan hukum tetap (inkracht van gewijsde). Sebelum ada putusan pengadilan tersebut, setiap pelaku yang diduga melakukan pemerkosaan melekat pada dirinya Asas Praduga Tak Bersalah (Presumption of Innocence) yang dijamin oleh Undang-Undang. Dalam waktu 40 hari yang diberikan oleh Peraturan Pemerintah untuk pembolehan aborsi akibat pemerkosaan tersebut, tidak akan cukup untuk menunggu proses akhir dari keseluruhan proses yang dilalui oleh seseorang yang di duga melakukan pemerkosaan, lebih lagi jika misalnya seseorang yang diduga itu masih melakukan upaya hukum dan banding kasasi sampai ketingkat Mahkamah Agung (MA), tentu semua ini membutuhkan waktu yang begitu panjang dan bahkan secara kasar dapat dikatakan, bahwa sekalipun wanita tersebut sudah melahirkan bayi yang

\footnotetext{
${ }^{17}$ J.Guwandi, Hukum Medik (Medical Law), Jakarta, Balai Penerbit FKUI, 2005, Hal.13.

${ }^{18}$ Marwan Effendy, Teori Hukum dari Persfektif Kebijakan, Perbandingan dan Harmonisasi Hukum Pidana, Referensi, Jakarta, 2014, Hal. 7.
}

dikandungnya, proses hukum juga belum selesai apabila kita mengacu pada KUHAP. ${ }^{19}$

\section{Pandangan Dari Undang-Undang Dasar 1945 Yang Telah Diamandemen}

Secara prinsip Undang-Undang Dasar tidak mengatur masalah kebolehan atau larangan terhadap abortus provocatus terutama yang terjadi karena suatu tindak pemerkosaan. Namun Undang-Undang Dasar 1945 yang diamandemen memberikan perlindungan terhadap hak-hak asasi perempuan sebagai kelompok yang rentan. Beberapa pasal yang terkait permasalahan terhadap perlindungan hak reproduksi perempuan dapatlah dianalisis dari pasal-pasal yang tertuang dalam $B A B X A$ Pasal 28 terutama Pasal 28 A, 28 D, dan Pasal $28 \mathrm{H}^{20}$

\section{Undang-Undang Nomor 36 Tahun 2009 tentang Kesehatan}

Kutipan terhadap Pasal 75 ayat (2) menyatakan bahwa "larangan sebagaimana dimaksud pada ayat (1) bahwa setiap orang dilarang melakukan aborsi) dapat dikecualikan berdasarkan; "a. indikasi kedaruratan medis yang di deteksi sejak usia dini kehamilan, baik yang mengancam nyawa ibu daan/atau janin, yang menderita penyakit genetik berat dan/atau cacat bawaan, maupun yang tidak dapat diperbaiki sehingga menyulitkan bayi terseebut hidup diluar kandungan; atau $b$. Kehamilan akibat pemerkosaan yang dapat menyebabkan trauma psikologis bagi korban pemerkosaan" ${ }^{21}$ Legalisasi abortus provocatus tersebut tidak terlepas dari ketentuan pasalpasal terdahulu tentang makna kesehatan yakni "Keadaan sehat, baik secara fisik, mental, spiritul maupun social yang memungkinkan setiap orang untuk hidup produktif secara sosial dan ekonomis" dan hak atas kesehatan itu sendiri.

\footnotetext{
19 Herniawati S.H, "Masa Gestasi Dalam Hubungan Legalitas Aborsi Akibat Pemerkosaan Berdasarkan Peraturan Pemerintah Nomor 61 Tahun 2014 Tentang Kesehatan Reproduksi Menurut Tinjauan Normatif", Tesis Sekolah Tinggi IImu Hukum Soelthan M Tsjafioddin, hal.911.

${ }^{20}$ Rika Saraswati, Perempuan dan Penyelesaian Kekerasan Dalam Rumah Tangga, Cetakan Kedua, PT. Citra Aditya Bakti, Bandung, 2009, hal.18.

${ }^{21}$ Lihat Undang-Undang Nomor 36 Tahun 2009 tentang Kesehatan Pasal 75.
} 
Ketentuan batas usia kehamilan yang diizinkan untuk aborsi yakni 6 minggu dihitung sejak hari pertama haid terakhir. Persyaratan ini akan sulit diterapkan terutama yang terkait pada korban pemerkosaan karena akan sangat sulit mengetahui kehamilan sejak usia dini. Pada umumnya kehamilan baru diketahui setelah berusia di atas 10 minggu (kurang lebih 3 bulan). Hal ini perlu dicermati untuk mencegah ancaman sanksi pidana bagi pelaku aborsi maupun korban pemerkosaan karena dianggap tidak memenuhi persyaratan Pasal 76 Undang-Undang Nomor 36 Tahun 2009 tentang Kesehatan tersebut. Terlebih bagi kalangan praktisi medis (dokter) bahwa aborsi sebelum 20 minggu masih diperbolehkan. Oleh karena itu Pemerintah harus lebih arif dalam menuangkan berbagai aturan pelaksana terkait penyelenggara aborsi ini agar pihak yang memang membutuhkan tindakan tersebut tetap mendapatkan perlindungan hukum yang jelas. $^{22}$

\section{Undang-Undang Nomor 39 Tahun 1999 tentang Hak Asasi Manusia}

Hak wanita diatur dalam Bagian IX Pasal 45 sampai dengan Pasal 51 Undang-Undang Nomor 39 Tahun 1999 tentang Hak Asasi Manusia. Meski secara implisit tidak disebutkan tentang hak menentukan dirinya sendiri di bidang reproduksi, namun dapatlah dianalisis melalui beberapa pasal. Pasal 45 UndangUndang Nomor 39 Tahun 1999 tentang Hak Asasi Manusia menyebutkan bahwa "hak wanita dalam Undang-Undang ini adalah hak asasi manusia". Dengan demikian dapat disimpulkan bahwa seorang wanita/perempuan pun mempunyai hak yang sama dalam pemenuhan hak asasinya sebagai seorang manusia. Pasal 3 ayat (1) Undang-Undang Nomor 39 Tahun 1999 tentang Hak Asasi Manusia menyebutkan bahwa "setiap orang dilahirkan bebas dengan harkat dan martabat manusia yag sama dan sederajat". Sementara dalam ayat (2) disebutkan bahwa "setiap orang berhak atas pengakuan, jaminan, perlindungan dan pengakuan hukum yang adil serta mendapat kepastian hukum dan pengakuan

\footnotetext{
22 Kusmaryano, SCJ, Kontroversi Aborsi, Gramedia
} Widiasarana Indonesia, Jakarta, 2002, hal.203. yang sama di depan hukum". ${ }^{23}$ Pasal ini memberikan hak yang sama pada perempuan untuk mendapatkan pengakuan penuh terhadap hak-hak asasi terkait dengan fungsi dan sistem reproduksinya termasuk menentukan nasib dirinya sendiri. ${ }^{24}$

\section{PENUTUP}

\section{A. Kesimpulan}

1. Pembenaran aborsi bagi korban pemerkosaan didasarkan pada Pasal 75 Undang-Undang Nomor 36 Tahun 2009 tentang Kesehatan dan Pasal 31 Peraturan Pemerintah Nomor 61 Tahun 2014 tentang Kesehatan Reproduksi. Perlindungan dan pengakuan terhadap hak reproduksi pada prinsipnya merupakan pengakuan terhadap hak untuk hidup dan mempertahankan hidupnya. Hak setiap perempuan untuk mendapatkan kehidupan yang sehat secara lahir batin dan sosial dalam lingkup perlindungan hukum. Dalam hal ini artinya apabila ada hal-hal yang mengancam hidup dan kehidupan perempuan yang menyebabkan dirinya berada dalam keadaan yang tidak sehat dan sejahterah maka ia berhak diberikan pelayanan kesehatan dan perlindungan hukum sesuai kebutuhan dirinya.

2. Legalisasi abortus provocatus karena pemerkosaan merupakan suatu implementasi pemenuhan hak asasi perempuan terutama di bidang kesehatan reproduksi. Meski sebagian besar instrument HAM dan peraturan perundang-undangan tentang HAM tidak memberikan pernyataan eksplisit namun hak menentukan diri sendiri untuk mendapatkan hak atas derajat kesehatan yang setinggi-tingginya termasuk di dalam menentukan kapan seorang perempuan akan hamil dan melahirkan. Negara mempunyai kewajiban untuk membentuk peraturan pemerintah tentang mekanisme dan persyaratan

\footnotetext{
${ }^{23}$ Lihat Undang-Undang Nomor 39 Tahun 1999 tentang Hak Asasi Manusia (HAM), Pasal 3.

${ }^{24}$ Arrie Budhiartie, "Legalisasi Abortus Provocatus Karena Pemerkosaan Sebagai Implementasi Hak Asasi Perempuan", Artikel dimuat dalam: Jurnal Fakultas Hukum Universitas Jambi, Volume 13, No.2, hal.17, Juli Desember 2011.
} 
terhadap suatu tindakan abortus provocatus akibat pemerkosaan tersebut agar tujuan utama dari legalisasi dan diskriminalisasi tersebut dapat terwujud dan tidak memungkinkan untuk dijadikan peluang lahirnya tindak pidana baru. Melalui Peraturan Pemerintah yang diamanatkan oleh Undang-Undang Kesehatan sebagai sebuah aturan pelaksana, diharapkan dapat memberikan perlindungan hukum yang jelas perempuan yang menginginkan tindakan abortus provocatus serta tenaga kesehatan yang melakukan pelayanan aborsi.

\section{B. Saran}

1. Agar legalisasi tindakan abortus provocatus tersebut tidak disalahgunakan dan diartikan sebagai legalisasi tindakan hubungan seks bebas, maka pemerintah harus segera mengeluarkan Peraturan Pelaksana tentang hal-hal terkait pelaksanaan tindakan tersebut, yakni:

a. Peraturan Pelaksana tentang izin dan Penunjukan Rumah Sakit penyelenggara tindakan;

b. Peraturan Pelaksana tentang kewenangan pihak-pihak tertentu dalam menetapkan ada tidaknya tindak pidana pemerkosaan;

c. Peraturan Pelaksana tentang tim konseling dan rehabilitasi terhadap korban pemerkosaan.

Disamping itu perlu dilakukan pembenahan sistem penegakan hukum melalui upaya peningkatan kesadaran aparat penegak hukum terhadap proses penyelesaian hukum suatu tindak pidana pemerkosaan agar tidak menimbulkan penderitaan lain bagi korban secara mental/psikologis maupun materiil.

2. Perlunya langkah aktif bagi korban pemerkosaan agar melaporkan segera mungkin peristiwa hukum yang dialaminya. Tidak jarang ditemui korban pemerkosaan yang tidak segera melaporkan peristiwa tersebut karena masih mengedepankan musyawarah antara keluarga korban dan keluarga pelaku pemerkosaan untuk mengambil langkah-langkah yang benar sesuai dengan keyakinannya. Dan juga perlunya sinergitas antara aparat hukum dan tenaga kesehatan dalam upaya memberikan perlindungan hukum bagi korban pemerkosaan yang beerujung pada kehamilan.

\section{DAFTAR PUSTAKA}

BUKU

Abdullah Marlang, Pengantar Hukum Indonesia, ASPublishing, Makassar.

Abdul Mun'im Idries, Pedoman Ilmu Kedokteran Forensik, Jakarta, Binarupa Aksara, 2007.

Abdul Wahid dan Muhammad Irfan, "Perlindungan Korban Kekerasan Seksual", PT.Refika Aditama, Cetakan Kedua, Bandung, 2011.

Adami Chazawi, Malpraktek Kedokteran Tinjauan Norma dan Dktrin Hukum, Bayumedia, Malang, 2007.

Hamzah Andi, Terminologi Hukum Pidana, (Editor) Tamizi, Ed. 1. Cet. 1. Sinar Grafika, Jakarta, 2008.

Hendrik, Etika dan Hukum Kesehatan, Buku Kedokteran EGC, Jakarta, 2014.

J.Guwandi, Hukum Medik (Medical Law), Jakarta, Balai Penerbit FKUI, 2005.

Johnny Ibrahim, Teori dan Metodologi Penelitian Hukum Normatif, Bayu Media, Surabaya, 2007.

Kusmaryano, SCJ, Kontroversi Aborsi, Gramedia Widiasarana Indonesia, Jakarta, 2002.

Laden Marpaung, Tindak Pidana Terhadap Nyawa dan Tubuh, Sinar Grafika, Jakarta, 2000.

Moerti Hadiati Soeroso, Kekerasan Dalam Rumah Tangga (KDRT), Cetakan Pertama, Sinar Grafika, Jakarta, 2010.

Machli Riyadi, dan Lidia Widia S.ST.M.Kes, op. cit.

M.Hadjon, Philipus, Perlindungan Hukum Bagi Rakyat di Indonesia, Bina IImu, Surabaya, 1987.

Niken Savitri, HAM Perempuan (Kritik Teori Hukum Feminis Terhadap 
KUHP), PT. Refika Aditama, Cetakan Pertama, Bandung, 2008.

P.A.F. Lamintang, Hukum Pidana Indonesia, Sinar Bandung, 1984.

Nasution, Bahdar Johan, Hukum Kesehatan, Rineka Cipta, Jakarta, 2005.

Rocky Marbun, Deni Bram, Yuliasara Isnaeni dan Nusya S, Kamus Lengkap (Mencakup Istilah Hukum \& Perundang-undangan Terbaru, Cetakan Pertama, Visimedia, Jakarta, 2012.

Rika Saraswati, Perempuan dan Penyelesaian Kekerasan Dalam Rumah Tangga, Cetakan Kedua, PT. Citra Aditya Bakti, Bandung, 2009.

Riyadi, Macli, Etika dan Hukum Kebidanan, Nuha Medika, Yogyakarta, 2016.

Silalahi, Ulber, Metode Penelitian Sosial Kuantatif, Relika Aditama, Jakarta, 2006.

Siswati, Sri, Etika dan Hukum Kesehatan Dalam Perspektif Undang-Undang Kesehatan, Rajawali pers, Jakarta, 2013.

Soeroso, Moerti Hadiati, Kekerasan Dalam Rumah Tangga (KDRT), Cetakan Pertama, Sinar Grafika, Jakarta, 2010.

Soekidjo Notoatmodjo, Etik dan Hukum Kesehatan, PT. Rineka Cipta, Jakarta, 2010.

Soerjono Soekanto, Pengantar Penelitian Hukum, Cetakan III, Jakarta Badan Penerbit Fakultas Hukum Universitas Indonesia, 2005.

Tim Penyusun Kamus Pusat Pembinaan Bahasa, Kamus Besar Bahasa Indonesia, Balai Pustaka, Jakarta, 1989.

Ulber Silalahi, Metode Penelitian Sosial Kuantatif, Relika Aditama, Surabaya, 2004.

Waluyadi, IImu Kedokteran Kehamilan Dalam Perspektif Peradilan dan Aspek Hukum Praktik Kedokteran, Djambatan, Jakarta.

Wahid, Abdul, Perlindungan Korban Kekerasan Seksual, PT.Refika Aditama,
Cetakan Kedua, Bandung, 2011.

Perlindungan Terhadap Korban Kekerasan Seksual, Refika Aditama, Bandung, 2001.

Yahya Ahmad, Zein Problematika Hak Asasi Manusia, Edisi Pertama, Liberty, Yogyakarta, 2012.

\section{JURNAL/KARYA ILMIAH}

Aji Mulyana, Perlindungan Hukum Terhadap Perempuan, Artikel dimuat dalam: Jurnal Wawasan Yuridika, Universitas Suryakancana, Vol.1, No.2, 30 September 2017.

Arrie Budhiartie, "Legalisasi Abortus Provocatus Karena Pemerkosaan Sebagai Implementasi Hak Asasi Perempuan", Artikel dimuat dalam: Jurnal Fakultas Hukum Universitas Jambi, Volume 13, No.2, Juli - Desember 2011.

Bunga Mutiara Batalipu, "Kajian Yuridis Atas Legalisasi Aborsi Dalam Kasus Pemerkosaan" Artikel dimuat dalam: Jurnal Lex Crimen, Vol.5, No.2, 12 Mei 2016.

Herniawati, "Masa Gestasi Dalam Hubungan Legalitas Aborsi Akibat Pemerkosaan Berdasarkan Peraturan Pemerintah Nomor 61 Tahun 2014 Tentang Kesehatan Reproduksi Menurut Tinjauan Normatif', Tesis Sekolah Tinggi Ilmu Hukum Soelthan M Tsjafioddin.

Mufliha Wijayati, "Aborsi Akibat Kehamilan Yang Tidak Di inginkan", Artikel dimuat dalam: Jurnal Studi Keislaman, Vol.5, No.1, Juni 2015.

Rohmawati, "Tinjauan Hukum Islam Terhadap Legalitas Aborsi Akibat Pemerkosaan Dalam PP No.61 Tahun 2014", Artikel dimuat dalam: Jurnal Ahkam, Volume 3, No.1, Juli 2015.

Trisnawanty Abdullah, "Aspek Yuridis Terhadap Tindakan Aborsi Pada Kehamilan Akibat Perkosaan", Skripsi Fakultas Hukum 
Universitas Sam Ratulangi Manado, (Manado, Perpustakaan Fakultas Hukum Universitas Sam Ratulangi Manado, 2015).

Trini Handayani, "Perlindungan Dan Hukum Terhadap Penegakan Hukum Terhadap Kasus Kekerasan Seksual Pada Anak", Artikel dimuat dalam Jurnal Hukum Mimbar Justitia, Vol.2, Nomor 2, Mei 2017.

Wayan Resmini, "Pandangan Norma Agama Dan Norma Hukum Tentang Aborsi", Artikel dimuat dalam: Jurnal Ilmiah

FKIP.Univ.Muhammadiyah

Mataram, Vol.4. No.2, September 2017.

\section{PERATURAN PERUNDANG-UNDANGAN}

Undang-Undang Dasar Negara Republik Indonesia Tahun 1945

Undang-Undang Nomor 7 Tahun 1946 tentang Kitab Undang-Undang Hukum Pidana

Undang-Undang Nomor 36 Tahun 2009 tentang Kesehatan.

Undang-Undang Nomor 39 Tahun 1999 tentang Hak Asasi Manusia.

Peraturan Pemerintah Nomor 61 Tahun 2014 tentang Kesehatan Reproduksi

\section{INTERNET}

Igraa Runi, "Catatan Tahun 2019 Komnas Perempuan: Kasus Kekerasan Terhadap Perempuan Meningkat", https:// www. komnasperempuan.

go.id//catatan -tahun- 2019komnas-perempuan- kasusperempuan meningkat, Di akses tanggal 11 September 2019, pukul 14:52 Wita.

"Keteraturan norma, sosial, dan hukum", https:// media. neliti. com/meia/publications/ 80721ID- keteraturan -sial-normadan-hukum-sebua.pdf, diakses pada tanggal 28 Oktober 2019, Pukul 13:20 Wita.

\section{SUMBER-SUMBER LAINNYA}

Ahmad ALI, 2012, Menguak Teori Hukum (Legal Theory) dan Teori Peradilan (Judicialprudence) Termasuk Interpretasi Undang-Undang (Legisprudence), Kencana, Jakarta.

Kristi Poerwandari, Penghapusan Diskriminasi Terhadap Wanita, Bandung, Rineka Cipta, 2000.

Dedi Mulyadi, Kebijakan Legislasi Tenang Sanksi Pidana Pemilu Legislatif, Gramata Publishing, Jakarta, 2012.

Sianturi S.R, Asas-Asas Hukum Pidana di Indonesia, Alumni AhaemPetehaem, Jakarta, 1986.

Saifullah, Aborsi dan Pertimbangan Hukum Terhadap Kasus Pemerkosaan, Artikel dimuat dalam Jurnal Mimbar Hukum, vol. 3, no.2, Juli 2013.

Marwan Effendy, Teori Hukum dari Persfektif Kebijakan, Perbandingan dan Harmonisasi Hukum Pidana, Referensi, Jakarta, 2014.

Lilien Eka Candra, Tanpa Indikasi Medis Ibu, Aborsi sama dengan Kriminal, Bayu Media, Surabaya, Mei 2010.

Suryno Ekotomo, Abortus Provocatus Bagi Korban Pemerkosaan, Perspektif Viktimologi, Kriminologi dan Hukum Pidana, Penerbit Universitas Atma Jaya, Yogyakarta, 2001.

H.A.K. Moch. Anwar, Hukum Pidana Kajian Khusus, Alumni, Bandung, 2006. 